\title{
TEST OF MODIFIED ULTRA-HIGH MOLECULAR WEIGHT POLYETHYLENE FOR PROSTHETIC REPAIR OF THE OSSICULAR CHAIN
}

\author{
Oleg Khorov ${ }^{1}$, Vasily Struk ${ }^{2}$, Uladzimir Novasialetski ${ }^{1}$ \\ ${ }^{1}$ Department of Otorhinolaryngology, Grodno State Medical University, Belarus \\ ${ }^{2}$ Faculty of Innovative Technologies of Mechanical Engineering, Grodno State University, Belarus
}

Corresponding author: Novasialetski Uladzimir, 80 ul. Gorkogo, Grodno 230009, Belarus, Phone: +375-152-43-54-51, e-mail: novasialetski@rambler.ru

\begin{abstract}
Background: Our aim was to evaluate the effect of implantation of a surface-modified ultra-high molecular weight polyethylene (UHMWPE) of high density into a rabbit ear's bulla in terms of biochemical and immunological blood parameters and middle ear tissue morphology.
\end{abstract}

Material and Methods: Exactly 35 rabbits were used, divided into 3 groups. In the $1^{\text {st }}$ group the ears were implanted with a piece of UHMWPE $6 \mathrm{~mm}$ long and $1 \mathrm{~mm}$ in diameter the surface of which had been modified with a laser. In the $2^{\text {nd }}$ group similar titanium implants were used. The $3^{\text {rd }}$ group was a control ( 5 rabbits). The $1^{\text {st }}$ and $2^{\text {nd }}$ groups comprised 15 animals which were euthanased 15, 60, and 90 days after implantation (5 animals each).

Results: Comparison of the two experimental groups with the control group revealed no significant differences in biochemical and immunological blood parameters or tissue morphology in the middle ear at different times after surgery.

Conclusions: UHMWPE of high density can be regarded as a material suitable for developing prostheses for the ossicular chain.

Keywords: ultra-high molecular weight polyethylene $\bullet$ high density • ossiculoplasty • ossicular chain prosthesis

\section{PRUEBA DEL POLIETILENO MODIFICADO DE ULTRA ALTO PESO MOLECULAR EN LA REPARACIÓN PROTÉSICA DE LA CADENA OSICULAR}

\section{Sinopsis}

Introducción: Nuestro objetivo ha sido valorar el impacto de la implantación del polietileno de ultra alto peso molecular modificado en su superficie (UHMPWE) de gran densidad en la bulla tympanica del oído del conejo, en el contexto de parámetros bioquímicos e immunológicos de sangre y de morfología del tejido del oido medio.

Materiales y métodos: Se ha utilizado el número exacto de 35 conejos, divididos en 3 grupos. En el primer grupo se ha insertado al oído un fragmento de UHMPWE de $6 \mathrm{~mm}$ de largo y de diametro de $1 \mathrm{~mm}$, cuya superficie fue modificada con láser. En el segundo grupo se han utilizado los implantes similares de titanio. El tercer grupo ha sido el lote de control (5 conejos). El primer y segundo grupo estaban compuestos de 15 animales, que fueron sacrificados (respectivamente en grupos de 5 animales) 15, 60 y 90 días después de la implantación.

Resultados: La comparación de estos dos grupos experimentales con el lote de control no ha puesto de manifiesto diferencias significativas bioquímicas e immunológicas en los parámetros de sangre y de morfología del tejido del oído medio, en diferentes momentos después de la operación.

Conclusiones: UHMWPE de gran densidad puede ser considerado como material adecuado para elaboración de prótesis de cadena osicular.

Palabras clave: polietileno de ultra alto peso molecular, gran densidad, osiculoplástica, prótesis de cadena osicular 


\section{ИССЛЕДОВАНИЕ СВЕРХВЫСОКОМОЛЕКУЛЯРНОГО ПОЛИЭТИЛЕНА ВЫСОКОЙ ПЛОТНОСТИ В КАЧЕСТВЕ МАТЕРИАЛА ДЛЯ ПРОТЕЗИРОВАНИЯ ЦЕПИ СЛУХОВЫХ КОСТОЧЕК}

\section{Резюме}

Введение: Целью нашей работы являлась оценка влияния модифицированного сверхвысокомолекулярного полиэтилена высокой плотности (СВМПЭ) при его имплантации в буллу уха кролика на некоторые биохимические и иммунологические показатели крови, а также на морфологию тканей среднего уха.

Материалы и методы: Для эксперимента использовали 35 кроликов, которые были разделены на 3 группы. В первой группе в барабанную полость имплантировали материал из СВМПЭ длиной 6 мм и диаметром 1 мм с модифицированным лазером поверхностным слоем. Во второй группе использовали подобные титановые имплантаты, третья группа - контрольная (5 кроликов). Первая и вторая группы включали по 15 животных, со сроками выведения из эксперимента на 15, 60 и 90 дней после имплантации (по 5 кроликов в каждой серии)

Результаты: Сравнение экспериментальных групп между собой, а также с результатами контрольной группой не показало статистически значимых различий по биохимическим и иммунологическим показателям крови, а также морфологии тканей среднего уха в различные сроки после операции.

Заключение: Модифицированный СВМПЭ можно рассматривать как материал, пригодный для протезирования цепи слуховых косточек.

Ключевые слова: сверхвысокомолекулярный полиэтилен высокой плотности• оссикулопластика • протезы цепи слуховых косточек

\section{TEST ZMODYFIKOWANEGO POLIETYLENU O ULTRAWYSOKIEJ MASIE CZĄSTECZKOWEJ W PROTETYCZNEJ NAPRAWIE ŁAŃCUCHA KOSTECZEK SŁUCHOWYCH}

\section{Streszczenie}

Wstęp: Naszym celem była ocena wpływu wszczepienia powierzchniowo zmodyfikowanego polietylenu o ultrawysokiej masie cząsteczkowej (UHMWPE) o dużej gęstości do puszki bębenkowej ucha królika, w kontekście biochemicznych i immunologicznych parametrów krwi oraz morfologii tkanki ucha środkowego.

Materiały i metody: Wykorzystanych zostało dokładnie 35 królików, podzielonych na 3 grupy. W pierwszej grupie wszczepiono do uszu fragment UHMWPE o długości $6 \mathrm{~mm}$ i średnicy $1 \mathrm{~mm}$, którego powierzchnia została zmodyfikowana laserem. W drugiej grupie użyte zostały podobne tytanowe implanty. Trzecia grupa była kontrolną (5 królików). Pierwsza i druga grupa składała się z 15 zwierząt, które zostały uśpione (kolejno po 5 zwierząt) 15, 60 i 90 dni po implantacji.

Wyniki: Porównanie tych dwóch grup eksperymentalnych z grupą kontrolną nie ujawniło żadnych znaczących różnic biochemicznych i immunologicznych parametrach krwi oraz morfologii tkanki ucha środkowego, w różnych okresach czasowych po operacji.

Konkluzje: UHMWPE o dużej gęstości może być rozważane jako materiał odpowiedni do tworzenia protez dla łańcucha kosteczek słuchowych.

Słowa kluczowe: polietylen o ultrawysokiej masie cząsteczkowej • duża gęstość • oscyloplastyka • protezy łańcucha kosteczek słuchowych

\section{Background}

The question of how to create an ideal material for ossicular chain reconstruction after chronic destructive diseases of the middle ear still remains open $[1,2]$. The ideal prosthesis material should be biocompatible, stable, safe, easily insertable, and capable of optimal sound transmission. When the surgeon chooses a particular prosthesis, selection must be based on several factors, including compatibility and ease of configuring the prosthesis during surgery [3-5].

As well as bioinertness, implant materials need a layer of cartilage between the tympanic membrane or a transplant and the prosthesis. But even this does not exclude the possibility of extrusion after a long time in use. At the present stage of otosurgery, constructions from titanium, 
possessing plasticity, memory form effect, and biological compatibility with biological tissues, are successfully used. These properties make titanium the first choice in reconstructive plastic surgery of the middle ear [2,5-9].

Therefore the idea of developing an ossicular chain prosthesises based on new otosurgery polymers has appeared. In other areas of surgery (traumatology and in orthopedics, maxillofacial surgery, urology), ultra-high molecular weight polyethylene (UHMWPE) of high density is successfully used as an implant material [10-12]. A low coefficient of friction and low wear rate are significant properties of this polymer. Other important characteristics are: density corresponding to that of bone tissue, low weight in comparison with metals, very low water absorption, and minor swelling in biological liquids [11,13-15]. Before an alloplastic material can be used in the middle ear space, its reactions towards the surrounding tissue and special environment of the middle ear need to be examined carefully. In this context, a rabbit's middle ear has proved to be a suitable experimental model.

Within a scientific project on the development of ossicular chain prostheses, we have performed experimental preclinical research on animals to study various characteristics of UHMWPE of high density and with a modified surface layer $[11,13]$. Important factors are the dynamics of biochemical and immunological blood parameters and the histological examination of tissues in contact with the implant, allowing estimation of the bio-integration properties of allogenic materials. These factors allow us to characterize changes in homeostasis under the influence of an implant placed in the recipient's body [16].

The aim of our research is to evaluate the effect of UHMWPE after implantation in the bulla of the rabbit's ear in terms of biochemical and immunological blood parameters as well as on morphology of middle ear tissues. A comparison was done with titanium, widely used in otosurgery, and with results from a control group.

\section{Material and Methods}

For comparative analysis of the biointegration properties of UHMWPE and titanium we have developed an experimental model to study the effect of implants made from these materials on middle ear tissues and the organism in general. In this study 35 healthy rabbits of $1.5-2 \mathrm{~kg}$ and both sexes were used. Animals showed no signs of otitis media or external otitis.

All operative measures were carried out under adequate anesthesia according to the recommendations of the "Interdisciplinary Principles and Guidelines for the Use of Animals in Research, Testing, and Education" (New York Academy of Sciences, 1988). All experimental animals were divided into three groups. Groups 1 and 2 consisted of three series and included 15 animals (5 in each series). Group 3 was a control and consisted of 5 rabbits. Implants from UHMWPE (ISO 5834/2, Hoechst AG, Germany) were used in group 1 as a material for research. In group 2 titanium was used. Animals in the control group were not operated on. Cylindrical implants $6 \mathrm{~mm}$ long and $1 \mathrm{~mm}$ in diameter were used.
Modification of the surface of the UHMWPE implants was done using an IPL Quantum-15 laser with a Nd: YAG light source (wavelength $1.06 \mu \mathrm{m}$, pulse length $2.0 \mu \mathrm{s}, 10 \mathrm{im}$ pulses each of about $6 \mathrm{~J}$ ). A light-diffusing material was used as a substrate. Modification allows production of a material with particular physical and mechanical characteristics due to no compensated charge [17]. The prosthesis made from such a material possesses an internal electric field with prolonged molecular relaxation, improving the biocompatibility of the product. In addition, the effect of the laser creates a nanorelief similar to the surface of natural human auditory ossicles.

Before surgery, animals were anesthetized with $50 \mathrm{mg} / \mathrm{kg}$ Calypsol (Gedeon Richter, Budapest, Hungary). Myringotomy was carried out using a microsurgical needle. A sample of the material was implanted in the rabbit's middle ear under monitoring of an operating microscope. Implants were placed freely. The same procedure was done on the other side.

After surgery, animals were placed in the vivarium of the Central Research Laboratory of Grodno State Medical University. General condition of the rabbits and the status of the ear (presence of discharge) was visually observed. In all animals, blood samples for studying biochemical and immunological parameters were taken from the auricular vein on the $15^{\text {th }}, 60^{\text {th }}$, and $90^{\text {th }}$ days after implantation. In the control group, blood sampling was carried out once. After sampling, animals were taken out of the experiment by overdose with Thiopental solution. Sampling of tissues (bulla of the middle ear) with an implant from one or both sides was performed. The implant was retrieved. After that some samples were taken for histological research from sites in contact with the examined material. They were fixed in $10 \%$ neutral Formalinum solution, and then exposed to ethanol of increasing concentration by a reference technique [18]. Sections of $5 \mu \mathrm{m}$ were made, painted with hematoxylin and eosine, and studied under a microscope. The extent of lymphoid cellular infiltration in soft tissues (as a sign of inflammation), and the presence of perivascular inflammation, fibroblasts, new vessel growth, and micro hemorrhages were studied. The main morphological changes were estimated semi-quantitatively (in points) according to the following criteria: 0 points, lack of a sign; 1 point, weak evidence of a sign; 2 points, moderate evidence of a sign; 3 points, pronounced degree of a sign.

Biochemically, we used methods to quantitatively define blood components. Serum was produced by centrifugation using a reference technique $[19,20]$. Analysis was carried out on an automated photometer (PA-2600 Solar). The following indices were studied: content of total protein, total bilirubin, creatinine, glucose, and activity of aspartate aminotransferase enzyme. Total protein was defined by the biuretic method [19]. Creatinine was determined kinetically by the Jaffe color reaction (Popper's method) [19]. Glucose content was identified enzymatically with colorimetric completion [20]. Determination of activity of aspartate aminotransferase enzyme was carried out by a kinetic method [19]. Yendrashic-Kleggorn-Grof's method was used for detection of total bilirubin [20]. For immunology, we used heparinized whole blood and serum. Calculation 
Table 1. Biochemical results (mean, lower quartile, upper quartile) after implantation of a sample of ultra-high molecular weight polyethylene (UHMWPE) and titanium in the middle ear of rabbits. Column 2 is for the control group, and columns 9,10 , and 11 show probabilities $(p)$ of the null hypothesis involving the column numbers listed.

\begin{tabular}{|c|c|c|c|c|c|c|c|c|c|c|}
\hline Index & $\begin{array}{c}\text { Control } \\
\text { group } \\
n=5\end{array}$ & $\begin{array}{c}\text { UHMWPE } \\
15^{\text {th }} \text { day, } \\
n=5\end{array}$ & $\begin{array}{c}\text { UHMWPE } \\
60^{\text {th }} \text { day, } \\
n=5\end{array}$ & $\begin{array}{c}\text { UHMWPE } \\
90^{\text {th }} \text { day, } \\
n=5\end{array}$ & $\begin{array}{c}\text { Titanium } \\
15^{\text {th }} \text { day, } \\
n=5\end{array}$ & $\begin{array}{c}\text { Titanium } \\
60^{\text {th }} \text { day, } \\
n=5\end{array}$ & $\begin{array}{c}\text { Titanium } \\
90^{\text {th }} \text { day, } \\
n=5\end{array}$ & $\begin{array}{c}p \\
2-3-6 \\
n=15\end{array}$ & $\begin{array}{c}p \\
2-4-7 \\
n=15\end{array}$ & $\begin{array}{c}p \\
2-5-8 \\
n=15\end{array}$ \\
\hline 1 & 2 & 3 & 4 & 5 & 6 & 7 & 8 & 9 & 10 & 11 \\
\hline $\begin{array}{c}\text { Bilirubin } \\
\text { total, } \mu \mathrm{mol} / \mathrm{l}\end{array}$ & $\begin{array}{l}5.20 \\
(5.10 \\
5.30)\end{array}$ & $\begin{array}{l}5.20 \\
(5.15 \\
5.25)\end{array}$ & $\begin{array}{l}5.20 \\
(5.15 \\
5.25)\end{array}$ & $\begin{array}{l}5.40 \\
(4.75 \\
5.65)\end{array}$ & $\begin{array}{l}5.20 \\
(4.60 ; \\
5.30)\end{array}$ & $\begin{array}{l}5.90 \\
(5.80 \\
5.90)\end{array}$ & $\begin{array}{l}5.10 \\
(4.80 \\
5.20)\end{array}$ & 0.54 & 0.81 & 0.13 \\
\hline $\begin{array}{c}\text { Aspartate } \\
\text { aminotransferase } \\
\text { U/l }\end{array}$ & $\begin{array}{c}48.21 \\
(44.12 \\
56.21)\end{array}$ & $\begin{array}{l}35.61 \\
(35.48 \\
40.16)\end{array}$ & $\begin{array}{l}37.89 \\
(35.05 \\
40.66)\end{array}$ & $\begin{array}{l}41.25 \\
(38.34 \\
52.59)\end{array}$ & $\begin{array}{l}40.14 \\
(38.32 \\
40.16)\end{array}$ & $\begin{array}{l}45.36 \\
(43.61 \\
60.48)\end{array}$ & $\begin{array}{l}40.26 \\
(38.41 \\
41.14)\end{array}$ & 0.06 & 0.08 & 0.40 \\
\hline Glucose, mmol/l & $\begin{array}{l}7.12 \\
(6.93 \\
7.62)\end{array}$ & $\begin{array}{l}7.61 \\
(7.14 ; \\
7.78)\end{array}$ & $\begin{array}{l}7.38 \\
(6.65 \\
7.70)\end{array}$ & $\begin{array}{l}7.97 \\
(6.48 \\
9.09)\end{array}$ & $\begin{array}{l}8.14 \\
(7.16 ; \\
8.59)\end{array}$ & $\begin{array}{l}7.05 \\
(6.19 \\
7.12)\end{array}$ & $\begin{array}{l}7.05 \\
(6.48 \\
7.76)\end{array}$ & 0.97 & 0.23 & 0.88 \\
\hline Creatinine, $\mu \mathrm{mol} / \mathrm{l}$ & $\begin{array}{l}121.2 \\
(102.1 \\
124.3)\end{array}$ & $\begin{array}{l}105.2 \\
(101.6 \\
108.2)\end{array}$ & $\begin{array}{l}103.4 \\
(101.5 \\
106.7)\end{array}$ & $\begin{array}{l}119.8 \\
(107.6 \\
129.7)\end{array}$ & $\begin{array}{l}106.1 \\
(103.5 \\
109.6\end{array}$ & $\begin{array}{l}106.1 \\
(105.6 \\
137.5)\end{array}$ & $\begin{array}{l}112.8 \\
(106.4 \\
125.3)\end{array}$ & 0.76 & 0.65 & 0.85 \\
\hline Protein total, g/l & $\begin{array}{l}64.48 \\
(59.61 \\
66.71)\end{array}$ & $\begin{array}{l}63.32 \\
(62.33 \\
65.48)\end{array}$ & $\begin{array}{l}62.83 \\
(61.93 \\
64.40)\end{array}$ & $\begin{array}{l}73.03 \\
(64.07 \\
74.18)\end{array}$ & $\begin{array}{l}64.92 \\
(62.32 \\
66.91)\end{array}$ & $\begin{array}{l}62.51 \\
(61.48 \\
64.11)\end{array}$ & $\begin{array}{l}65.48 \\
(65.48 \\
71.52)\end{array}$ & 0.36 & 0.81 & 0.13 \\
\hline
\end{tabular}

of leucocyte concentration was carried out in Goryaev's chamber. Circulating immune complexes in blood serum were determined by Novikov's method based on a physical and chemical deposition in polyethylene glycol solution [21]. A suspension of golden staphylococcus was applied to assess phagocytic activity of neutrophils [21]. The micro method of complement titration was performed using ram erythrocytes [21].

Statistical analysis of results was done using the Statistica 6.0 program. Data were described as a median and an interquartile range. The Kuskal-Wallice method was applied to compare the three groups of animals. Histological data were described as a percentage ratio. Distinctions between groups were calculated by means of Mann-Whitney's U-criterion. In tests, the null hypothesis $(p)$ was calculated, and differences were considered statistically significant if $p<0.05$.

\section{Results}

Biochemical results are presented in Table 1.

Statistical comparison of the experimental animal groups and the control group using the Kruskel-Wallice test did not reveal any significant differences in the content of total bilirubin, aspartate aminotransferase, glucose, creatinine, or total protein in blood serum at various terms after operation (in all cases $p<0.05$ ).

Immunology data are shown in Tables 2, 3, and 4. Comparison of results did not reveal statistically significant differences in all cases in control and study groups $(p<0.05)$.

Morphological results are presented in Table 5. Results of Mann-Whitney's U-criterion are presented in the form of $p$.

\section{Discussion}

Before any alloplastic material can be used in the middle ear space, its reactions towards the surrounding tissue and special environment of the middle ear should be examined carefully. In this investigation, a modified UHMWPE of high density was used for the first time as a material for ossiculoplasty. Data on similar research in the literature was not found. There were many articles describing positive results of using titanium for prosthetic repair of the middle ear [3,5-9]. Our preclinical research confirms the biocompatibility of titanium implants.

The limited number of rabbits in our study was due to bioethics requirements. Considering the restricted number of animals, we used nonparametric statistical methods. The small number of experimental animals was in several cases the possible reason for big differences in the mean and quartiles for some parameters. Table 1 shows that in the study groups total protein level did not exceed physiological fluctuations on the $15^{\text {th }}, 60^{\text {th }}$, and $90^{\text {th }}$ days after operation, indicating that proteosintetic function of the liver was not impaired. UHMWPE did not interfere with total protein metabolism, and is equally nontoxic as titanium [19].

Examination of aminotransferases activity in blood serum is important, as high enzymatic activity arises in cases of toxic impact on the liver [19]. Our results show that the aspartate aminotransferase level remained normal on the $15^{\text {th }}, 60^{\text {th }}$, and $90^{\text {th }}$ days after UHMWPE implantation in the middle ear bulla. It confirms the safety of the polymer when implanted in the middle ear cavity.

Destructive and dystrophic changes in parenchymatous cells of the liver, caused by toxic substances, can induce hyperbilirubinemia [20]. Normal parameters of total bilirubin after operative intervention therefore show that 
Table 2. Leucocytic formula indexes after implantation of a sample of UHMWPE and titanium in the middle ear. Key as per Table 1.

\begin{tabular}{|c|c|c|c|c|c|c|c|c|c|c|}
\hline Index & $\begin{array}{c}\text { Control } \\
\text { group } \\
n=5\end{array}$ & $\begin{array}{c}\text { UHMWPE } \\
\begin{array}{c}15^{\text {th }} \text { day, } \\
n=5\end{array}\end{array}$ & $\begin{array}{c}\text { UHMWPE } \\
\begin{array}{c}60^{\text {th }} \text { day, } \\
n=5\end{array}\end{array}$ & $\begin{array}{c}\text { UHMWPE } \\
\begin{array}{c}90^{\text {th }} \text { day, } \\
n=5\end{array}\end{array}$ & $\begin{array}{c}\text { Titanium } \\
15^{\text {th }} \text { day, } \\
n=5\end{array}$ & $\begin{array}{c}\text { Titanium } \\
60^{\text {th }} \text { day, } \\
n=5\end{array}$ & $\begin{array}{c}\text { Titanium } \\
90^{\text {th }} \text { day, } \\
n=5\end{array}$ & $\begin{array}{c}p \\
2-3-6 \\
n=15\end{array}$ & $\begin{array}{c}p \\
2-4-7 \\
n=15\end{array}$ & $\begin{array}{c}p \\
2-5-8 \\
n=15\end{array}$ \\
\hline 1 & 2 & 3 & 4 & 5 & 6 & 7 & 8 & 9 & 10 & 11 \\
\hline $\begin{array}{l}\text { Leucocytes, } \\
\quad \times 10^{9} / 1\end{array}$ & $\begin{array}{c}2.42 \\
(2.20 ; 2.81)\end{array}$ & $\begin{array}{c}2.92 \\
(2.86 ; 3.85)\end{array}$ & $\begin{array}{c}3.63 \\
(3.08 ; 3.74)\end{array}$ & $\begin{array}{c}3.74 \\
(3.52 ; 3.80)\end{array}$ & $\begin{array}{c}3.30 \\
(3.08 ; 4.40)\end{array}$ & $\begin{array}{c}3.63 \\
(2.53 ; 5.15)\end{array}$ & $\begin{array}{c}4.13 \\
(3.52 ; 4.68)\end{array}$ & 0.13 & 0.33 & 0.23 \\
\hline $\begin{array}{l}\text { Band neutrophils, } \\
\%\end{array}$ & 0 & 0 & 0 & 0 & 0 & 0 & 0 & 1.00 & 0.58 & 1.00 \\
\hline $\begin{array}{c}\text { Segmented } \\
\text { neutrophils, \% }\end{array}$ & $\begin{array}{c}9 \\
(7 ; 10)\end{array}$ & $\begin{array}{c}14 \\
(13 ; 14)\end{array}$ & $\begin{array}{c}8 \\
(8 ; 8)\end{array}$ & $\begin{array}{c}12 \\
(10 ; 12)\end{array}$ & $\begin{array}{c}16 \\
(14 ; 28)\end{array}$ & $\begin{array}{c}12 \\
(12 ; 18)\end{array}$ & $\begin{array}{c}12 \\
(11 ; 13)\end{array}$ & 0.21 & 0.12 & 0.09 \\
\hline Basophiles,\% & 0 & 0 & 0 & 0 & $\begin{array}{c}0 \\
(0 ; 1)\end{array}$ & 0 & 0 & 1.00 & 0.31 & 0.37 \\
\hline $\begin{array}{c}\text { Eosinophils, } \\
\%\end{array}$ & $\begin{array}{c}3 \\
(2 ; 4)\end{array}$ & $\begin{array}{c}2 \\
(0 ; 2)\end{array}$ & $\begin{array}{c}4 \\
(2 ; 4)\end{array}$ & $\begin{array}{c}2 \\
(2 ; 3)\end{array}$ & $\begin{array}{c}2 \\
(1 ; 2)\end{array}$ & $\begin{array}{c}2 \\
(0 ; 2)\end{array}$ & $\begin{array}{c}4 \\
(3 ; 4)\end{array}$ & 0.44 & 0.09 & 0.31 \\
\hline $\begin{array}{c}\text { Monocytes, } \\
\%\end{array}$ & $\begin{array}{c}3 \\
(2 ; 4)\end{array}$ & $\begin{array}{c}3 \\
(2 ; 4) \\
\end{array}$ & $\begin{array}{c}4 \\
(2 ; 6)\end{array}$ & $\begin{array}{c}4 \\
(4 ; 5)\end{array}$ & $\begin{array}{c}5 \\
(4 ; 7)\end{array}$ & $\begin{array}{c}10 \\
(4 ; 13)\end{array}$ & $\begin{array}{c}4 \\
(3 ; 5)\end{array}$ & 0.45 & 0.33 & 0.10 \\
\hline $\begin{array}{c}\text { Lymphocytes } \\
\%\end{array}$ & $\begin{array}{c}84 \\
(80 ; 86)\end{array}$ & $\begin{array}{c}82 \\
(80 ; 84)\end{array}$ & $\begin{array}{c}84 \\
(84 ; 84)\end{array}$ & $\begin{array}{c}82 \\
(78 ; 82)\end{array}$ & $\begin{array}{c}72 \\
(66 ; 84)\end{array}$ & $\begin{array}{c}75 \\
(69 ; 78)\end{array}$ & $\begin{array}{c}80 \\
(78 ; 82)\end{array}$ & 0.27 & 0.36 & 0.08 \\
\hline
\end{tabular}

Table 3. Neutrophil physiological activity after implantation of a sample of UHMWPE and titanium in the middle ear. Key as per Table 1 .

\begin{tabular}{|c|c|c|c|c|c|c|c|c|c|c|}
\hline Index & $\begin{array}{c}\text { Control } \\
\text { group } \\
n=5\end{array}$ & $\begin{array}{l}\text { UHMWPE } \\
15^{\text {th }} \text { day, } \\
n=5\end{array}$ & $\begin{array}{c}\text { UHMWPE } \\
60^{\text {th }} \text { day, } \\
n=5\end{array}$ & $\begin{array}{l}\text { UHMWPE } \\
90^{\text {th }} \text { day, } \\
n=5\end{array}$ & $\begin{array}{c}\text { Titanium } \\
15^{\text {th }} \text { day, } \\
n=5\end{array}$ & $\begin{array}{c}\text { Titanium } \\
60^{\text {th }} \text { day, } \\
n=5\end{array}$ & $\begin{array}{c}\text { Titanium } \\
90^{\text {th }} \text { day, } \\
n=5\end{array}$ & $\begin{array}{c}p \\
2-3-6 \\
n=15\end{array}$ & $\begin{array}{c}p \\
2-4-7 \\
n=15\end{array}$ & $\begin{array}{c}p \\
2-5-8 \\
n=15\end{array}$ \\
\hline 1 & 2 & 3 & 4 & 5 & 6 & 7 & 8 & 9 & 10 & 11 \\
\hline $\begin{array}{l}\text { Phagocytic } \\
\text { number, c.u. }\end{array}$ & $\begin{array}{c}5.50 \\
(4.70 ; 5.80)\end{array}$ & $\begin{array}{c}6.00 \\
(5.20 ; 6.20)\end{array}$ & $\begin{array}{c}6.40 \\
(5.80 ; 7.60)\end{array}$ & $\begin{array}{c}6.60 \\
(4.70 ; 7.10)\end{array}$ & $\begin{array}{c}6.10 \\
(5.40 ; 6.60)\end{array}$ & $\begin{array}{c}6.20 \\
(6.00 ; 8.10)\end{array}$ & $\begin{array}{c}4.90 \\
(4.25 ; 5.70)\end{array}$ & 0.35 & 0.51 & 0.14 \\
\hline $\begin{array}{c}\text { Phagocytic } \\
\text { index,\% }\end{array}$ & $\begin{array}{c}62.0 \\
(60.0 ; 65.0)\end{array}$ & $\begin{array}{c}51.0 \\
(50.0 ; 60.0)\end{array}$ & $\begin{array}{c}60.0 \\
(60.0 ; 62.0)\end{array}$ & $\begin{array}{c}65.0 \\
(55.0 ; 68.0)\end{array}$ & $\begin{array}{c}48.0 \\
(40.0 ; 51.0)\end{array}$ & $\begin{array}{c}60.0 \\
(55.0 ; 70.0)\end{array}$ & $\begin{array}{c}45.0 \\
(43.0 ; 60.0)\end{array}$ & 0.11 & 0.18 & 0.16 \\
\hline
\end{tabular}

Table 4. Circulating immune complexes maintenance and complement level after implantation of a sample of UHMWPE and titanium in the middle ear. Key as per Table 1.

\begin{tabular}{|c|c|c|c|c|c|c|c|c|c|c|}
\hline Index & $\begin{array}{c}\text { Control } \\
\text { group } \\
n=5\end{array}$ & $\begin{array}{c}\text { UHMWPE } \\
15^{\text {th }} \text { day, } \\
n=5\end{array}$ & $\begin{array}{c}\text { UHMWPE } \\
\begin{array}{c}60^{\text {th }} \text { day, } \\
n=5\end{array}\end{array}$ & $\begin{array}{c}\text { UHMWPE } \\
\begin{array}{c}90^{\text {th }} \text { day, } \\
n=5\end{array}\end{array}$ & $\begin{array}{c}\text { Titanium } \\
15^{\text {th }} \text { day, } \\
n=5\end{array}$ & $\begin{array}{c}\text { Titanium } \\
60^{\text {th }} \text { day, } \\
n=5\end{array}$ & $\begin{array}{c}\text { Titanium } \\
90^{\text {th }} \text { day, } \\
n=5\end{array}$ & $\begin{array}{c}p \\
2-3-6 \\
n=15\end{array}$ & $\begin{array}{c}p \\
2-4-7 \\
n=15\end{array}$ & $\begin{array}{c}p \\
2-5-8 \\
n=15\end{array}$ \\
\hline 1 & 2 & 3 & 4 & 5 & 6 & 7 & 8 & 9 & 10 & 11 \\
\hline $\begin{array}{l}\text { Circulating } \\
\text { immune } \\
\text { complexes, c.u. }\end{array}$ & $\begin{array}{c}5.0 \\
(5.0 ; 9.0)\end{array}$ & $\begin{array}{c}14.0 \\
(11.0 ; 16.0)\end{array}$ & $\begin{array}{c}11.0 \\
(11.0 ; 12.0)\end{array}$ & $\begin{array}{c}17.0 \\
(15.0 ; 20.0)\end{array}$ & $\begin{array}{c}28.0 \\
(20.0 ; 44.0)\end{array}$ & $\begin{array}{c}8.0 \\
(6.0 ; 10.0)\end{array}$ & $\begin{array}{c}5.0 \\
(4.0 ; 13.0)\end{array}$ & 0.10 & 0.10 & 0.23 \\
\hline Complement, $\mathrm{Cl}_{50}$ & $\begin{array}{l}25.05 \\
(25.05 \\
25.05)\end{array}$ & $\begin{array}{l}16.70 \\
(16.70 \\
25.05)\end{array}$ & $\begin{array}{l}16.70 \\
(16.70 \\
16.70)\end{array}$ & $\begin{array}{l}25.05 \\
(16.70 \\
25.05)\end{array}$ & $\begin{array}{l}25.05 \\
(25.05 \\
25.05)\end{array}$ & $\begin{array}{l}33.40 \\
(16.70 \\
41.75)\end{array}$ & $\begin{array}{c}16.70(8.35 \\
25.05)\end{array}$ & 0.54 & 0.50 & 0.16 \\
\hline
\end{tabular}

modified UHMWPE had no toxic impact on the liver parenchyma or the organism as a whole.

Creatinine is an important component of filtrate nitrogen, and arginine, glycine, and methionine participate in its synthesis. Hypercreatininemia is considered an early index of developing renal failure [19]. In our research, implantation of UHMWPE did not have any effect on creatinine at any stage of observation, suggesting that UHMWPE does not interfere with metabolic processes.
Glucose concentration in the blood was also within physiological norms for the $15^{\text {th }}, 60^{\text {th }}$, and $90^{\text {th }}$ days after the operation, indicating that UHMWPE has no impact on carbohydrate metabolism.

The active phase of the immune system's fight against a foreign agent is characterized by certain shifts in the quantity and ratio of leukocytes of various sorts in blood. To determine an organism's reaction to implanted allogenic material, an immunogram of the peripheral blood can be used. 
Table 5. Histological results after implantation of a sample of UHMWPE and titanium in the middle ear of rabbits. Key as per Table 1 .

\begin{tabular}{|c|c|c|c|c|c|c|c|c|c|c|c|c|c|c|}
\hline Index & 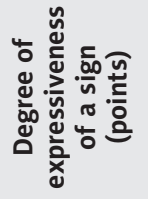 & 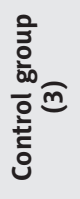 & 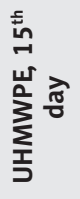 & 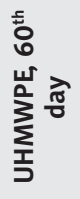 & 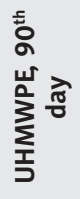 & 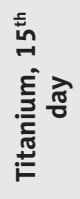 & 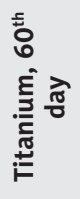 & 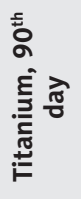 & $\begin{array}{c}p \\
4-7\end{array}$ & $\underset{5-8}{p}$ & $\underset{6-9}{p}$ & $\underset{3-4}{p}$ & $\begin{array}{c}p \\
3-5\end{array}$ & $\begin{array}{c}p \\
3-6\end{array}$ \\
\hline 1 & 2 & 3 & 4 & 5 & 6 & 7 & 8 & 9 & 10 & 11 & 12 & 13 & 14 & 15 \\
\hline \multirow{4}{*}{$\begin{array}{l}\text { Lymphoid cellular } \\
\text { infiltration, } \\
\%\end{array}$} & 0 & 40 & 50 & 20 & 50 & 20 & - & 50 & \multirow{4}{*}{0.27} & \multirow{4}{*}{0.74} & \multirow{4}{*}{1.00} & \multirow{4}{*}{0.62} & \multirow{4}{*}{0.32} & \multirow{4}{*}{0.72} \\
\hline & 1 & 30 & 30 & 30 & 25 & 50 & 50 & 25 & & & & & & \\
\hline & 2 & 30 & 20 & 50 & 25 & 30 & 50 & 25 & & & & & & \\
\hline & 3 & - & - & - & - & - & - & - & & & & & & \\
\hline \multirow{4}{*}{$\begin{array}{c}\text { Activity of an } \\
\text { inflammation, } \\
\%\end{array}$} & 0 & 60 & 80 & 50 & 62.5 & 60 & 16.7 & 100 & \multirow{4}{*}{0.41} & \multirow{4}{*}{0.59} & \multirow{4}{*}{0.21} & \multirow{4}{*}{0.45} & \multirow{4}{*}{0.41} & \multirow{4}{*}{0.79} \\
\hline & 1 & 40 & 20 & 20 & 12.5 & 30 & 66.6 & - & & & & & & \\
\hline & 2 & - & - & 30 & 25 & 10 & 16.7 & - & & & & & & \\
\hline & 3 & - & - & - & - & - & - & - & & & & & & \\
\hline \multirow{4}{*}{$\begin{array}{c}\text { Per vascular } \\
\text { inflammation, } \\
\%\end{array}$} & 0 & 40 & 80 & 40 & 50 & 50 & 33.3 & 75 & \multirow{4}{*}{0.41} & \multirow{4}{*}{0.91} & \multirow{4}{*}{0.34} & \multirow{4}{*}{0.13} & \multirow{4}{*}{0.65} & \multirow{4}{*}{0.93} \\
\hline & 1 & 60 & 20 & 40 & 37.5 & 40 & 50 & 25 & & & & & & \\
\hline & 2 & & - & 20 & 12.5 & 10 & 16.7 & - & & & & & & \\
\hline & 3 & & - & - & - & - & - & - & & & & & & \\
\hline \multirow{4}{*}{$\begin{array}{c}\text { Fibroblasts, } \\
\%\end{array}$} & 0 & 60 & 70 & 40 & 62.5 & 50 & 50 & 37.5 & \multirow{4}{*}{0.45} & \multirow{4}{*}{0.74} & \multirow{4}{*}{0.32} & \multirow{4}{*}{0.71} & \multirow{4}{*}{0.45} & \multirow{4}{*}{0.93} \\
\hline & 1 & 40 & 30 & 60 & 37.5 & 50 & 16.7 & 50 & & & & & & \\
\hline & 2 & - & - & - & - & - & 33.3 & 12.5 & & & & & & \\
\hline & 3 & - & - & - & & - & - & - & & & & & & \\
\hline & 0 & 70 & 90 & 70 & 50 & 50 & 50 & 37.5 & & & & & & \\
\hline New growth of vessels, & 1 & 30 & 10 & 20 & 50 & 50 & 33.3 & 62.5 & 13 & 052 & 067 & 045 & 091 & 048 \\
\hline & 2 & - & - & 10 & - & - & 16.7 & - & & & & & & \\
\hline & 3 & - & - & & & - & - & & & & & & & \\
\hline & 0 & 50 & 70 & 70 & 75 & 40 & 50 & 75 & & & & & & \\
\hline Micro hemorrhages, & 1 & 40 & 30 & 20 & 25 & 60 & 33.3 & 25 & 526 & 057 & م0 & 030 & 050 & 032 \\
\hline$\%$ & 2 & 10 & - & 10 & - & - & 16.7 & - & & & & & & \\
\hline & 3 & - & - & - & - & - & - & - & & & & & & \\
\hline $\mathrm{n}, \mathrm{nr}$ of tissue blocks & - & 10 & 10 & 10 & 8 & 10 & 6 & 8 & & & & & & \\
\hline
\end{tabular}

Neutrophil count is a key factor in determining organism intoxication. A complex multifold assessment of neutrophils can include determination of their content in blood, their morphological features, and physiological activity [21]. In our research the implantation of UHMWPE in the bulla of the rabbit did not lead to a statistically significant increase or decrease in the contents of band and segmented neutrophils in comparison with the control group or the titanium group.

Along with neutrophils, monocytes are the most phylogenetically old element of cell-like immunity (macrophages of different types). The macrophage is the main phagocytizing cell [21]. Therefore, the absence of a statistically significant difference in the quantity of monocytes in all the groups also suggests that UHMWPE is not perceived by an organism as a foreign body and does not provoke phagocytosis.

Eosinophils are regulators of vascular and infiltrative phases of inflammation, controlling biologically active substances secreted by basophiles and mast cells and neutralizing excessive quantities of discharged activated histamine. They produce a number of enzymes participating in the 
formation of substances, limiting the inflammation focus. A significant amount of eosinocytes is found in any inflammation focus or allergic reaction [21]. Lack of significant differences in the quantity of these cells between the study and control groups indicates that implants from UHMWPE are non-inflammatory.

The main function of basophiles is secretion of histamine, heparin, and serotonin at the site of foreign bodies which promote formation of an inflammatory focus and congestion [21]. Statistically significant differences in the quantity of basophiles were not found in all study groups, nor in the control group.

Lymphocytes are immune cells responsible for the high specificity of the immune response. There are two main types of lymphocytes: T-lymphocytes providing cell-like immunity, and V-lymphocytes responsible for antibody formation. Lymphocytes circulating in the blood are generally mature cells, and lymphocytes and molecular components of their interaction are signs of pathogenesis from immunodeficiency conditions, infectious, allergic, and oncologic diseases, transplant conflicts, and autoimmune diseases [21]. The result of our examination show that the number of lymphocytes did not differ significantly in all groups of experimental animals.

Nowadays the most widespread method of neutrophil physiological activity involve an assessment based on determining different stages of phagocytosis activity. For this purpose we measured a phagocytic index characterizing the level of neutrophils participating in phagocytosis and the phagocytic number - the average quantity of microbes absorbed by one neutrophil. Toxic substances can also suppress phagocytosis function [21]. In our research both indices showed no statistically significant difference between groups.

Circulating immune complexes in blood can indicate various inflammatory processes in an organism and can be an index of autoimmune disease. These complexes form and circulate in the blood stream in response to a foreign agent. Formation of circulating immune complexes is a physiological mechanism for protecting the organism, leading to fast removal of endogenic and exogenetic antigens. Their increased activity happens at the beginning of an infection, an allergic reaction, or an autoimmune disease [21]. The complement, in its turn, represents a group of plasma factors which are present in blood in the form of inactive proenzymes activating each other in a particular sequence. It participates in binding by antibodies of the antigens which intrude into an organism; it promotes lysis, agglutination, and opsonization of foreign cells [21]. In our research the maintenance of circulating immune complexes and level of a complement in the blood of UHMWPE-implanted animals did not statistically differ from the same parameters in the titanium group or the control group throughout the entire period of observation.

Microscopy of tissue specimens did not show any sharply increased expression of lymphoid cellular infiltration. In certain cases we did observe moderate signs of inflammation; however, these signs were also observed in some preparations from the middle ear tissues of control group animals. This indicates that there was no relationship between the state of the implanted rabbit's bulla and observed pathological changes. The results of the experiment show that at various times after the operation UHMWPE had the same impact on the morphology of contact surfaces of the middle ear soft tissues as titanium implants.

Overall, the study groups showed no significant statistical differences from the control group, giving grounds for considering that modified UHMWPE has no pathological impact on local or body-wide homeostasis.

\section{Conclusions}

1. On the basis of our data the modified UHMWPE of high density is a safe, bioinert material and does not upset homeostasis or cause local reaction in middle ear tissue.

2. The modified UHMWPE of high density can be considered as a material suitable for further development of ossicular chain prostheses.

\section{Acknowledgements}

Special gratitude goes to M. Zubricki for help in histology and to V. Sheibak for help in biochemistry and immunology.

\section{References:}

1. Pluzhnikov MS, Diskalenko VV, Kurmashova LM. The current state of a problem of surgical rehabilitation of patients with chronic inflammatory diseases of a middle ear. Vestnik otorinolaringologii, 2006; 5: 31-34.

2. Weerda H. History of auricular reconstruction. Adv Otorhinolaryngol, 2010; 68: 1-24.

3. Sitnikov VP, Anikin IA, Chernushevich AI, Zavarzin BA, Anikin MI. Use of autografts and implants at ossiculoplasty. Vestnik otorinolaringologii, 2006; 2: 38-41.

4. Khorov OG, Melanyin VD. Surgical treatment of patients by the destructive inflammation of middle ear. Grodno: GrSMU, 2001.

5. Chernushevich AI, Aleksandrov IN. The comparative characteristic of the prosthesises used at ossiculoplasty. Russian Otorhinolaryngology, 2004; 1: 113-15.
6. Semenov FV, Volik AK. Clinical and audiological methods of an assessment of effectiveness ossiculoplasty with use of titanic prosthesises at surgical treatment of patients by chronic inflammation of middle ear. Russian Otorhinolaryngology, 2004; 4: 145-48.

7. Luers JC, Huttenbrink KB, Beutner D. Incus to stapes footplate reconstruction of the ossicular chain using titanium implants. Clin Otolaryngol, 2010; 35(2): 161-62.

8. Ceccato SB, Maunsell R, Morata GC, Portmann D. Revue Comparative results of type II ossiculoplasty: incus transposition versus titanium PORP (Kurz). Rev Laryngol Otol Rhinol, 2005; 126(3): 175-79.

9. Dalchow CV, Grün D, Stupp HF. Reconstruction of the ossicular chain with titanium implants. Otolaryngology-Head and Neck Surgery, 2001; 125(6): 628-30. 
10. Vasilenko SP, Nikolaev MT, Nikolaev PM. Polymeric and ceramic-metal materials in reconstructive and plastic surgery of posttraumatic craniofacial damages. Russian Otorhinolaryngology, 2003; 4: 86-90.

11. Pinchuk of HP, Nikolaev VI, Tsvetkova EA. Prosthetic repair of joints: technical and medical-biological aspects. Gomel: IMMS NASB, 2003.

12. Dong, HY, Joon HN. Readjustable Sling Procedure for the Treatment of Female Stress Urinary Incontinence with Intrinsic Sphincter Deficiency: Preliminary Report. Korean J Urol, 2010; 51(6): 420-25.

13. Struk VA. Materials science. Minsk: Data-processing center of the Ministry of Finance; 2008.

14. Avdeychik SV. Nanocomposition machine-building materials: experience of development and application. Grodno: GrSU, 2006.
15. Andreev IN. Ultra-high molecular weight polyethylene of high density. Leningrad: Chemistry, 1982.

16. Razdorsky VV. Nickelid titanium implants biocompatibility evaluation in animal. Odontology, 2008; 6: 9-12.

17. Sorokin VG, Eysymont EI. Influence of a laser radiation on structural parameters of polymeric materials. Vestnik of GrSU, 2009; 2(82): 109-16.

18. Sapoznicov AG, Dorosevich AE. Histologic and microscopic technique: management. Smolensk: SAU, 2000.

19. Kamyshnikov VS. Directory on clinical-biochemical laboratory diagnostics. Part 1. Minsk: Belarus, 2002.

20. Kamyshnikov VS. Directory on clinical-biochemical laboratory diagnostics. Part 2. Minsk: Belarus, 2002.

21. Novikov DK, Novikova VI. Immune status assessment. Moscow: Medicine, 1996. 